\title{
Health Care : Current Reviews
}

\section{Plasminogen drug product stability study for intended use in ligneous conjunctivitis}

\section{Alfonso Salvatore*, Alessandro Carluccia, Marialetizia Carforaa, Zelinda Raiaa, Chi- ara Orazzoa, Valentina Maielloa, Marcella Maddalunoa, Renato Marinielloa, Luca Sanguignoa, Ciro Battagliaa, Roberto Creaa, Marta Bellinia, Anna Falboa and Ester Ascionea}

\author{
Kedrion Biopharma, Italy
}

\section{Abstract}

Background: Ligneous conjunctivitis is rare pathology associated to congenital Type 1 plasminogen deficiency. It is characterized by the formation of fibrin rich pseudomebranes.

A Plasminogen-based drug has been manufactured by Kedrion biopharma and delivered to patients as compassionate use, showing its efficacy in regression and recurrence prevention of pseudomembranes. The plasminogen drug product is currently stored at $<-20^{\circ} \mathrm{C}$. Alternative storage conditions for patient use were investigated to establish drug product stability after thawing.

Study Design and Methods: The analyzed storage conditions were: the Refrigerator $\left(2-8^{\circ} \mathrm{C}\right)$, room temperature $\left(\mathrm{RT}, 20-25^{\circ} \mathrm{C}\right)$ and high temperature $\left(40^{\circ} \mathrm{C}\right)$.

108 Vials of Drug were thawed at RT and divided into three groups to perform three independent studies. 36 vials for each group were stored at $25^{\circ} \mathrm{C}$ or $40^{\circ} \mathrm{C}$ in climatic chamber or $2-8^{\circ} \mathrm{C}$ in a refrigerator. Time points were provided and main product Critical Quality Attributes (CQA) were analyzed: Protein Concentration $(0.7-1.3 \mathrm{mg} / \mathrm{mL})$, Plasminogen Potency $(>5.0 \mathrm{U} / \mathrm{mL})$, Protein Composition (SDS-Page, Plasminogen> 90\%), Plasmin Activity ( $<0.005 \mathrm{UI} / \mathrm{mL})$. The acceptance criteria (AC) were based on the Product Specifications when properly stored.

Results: CQA AC In 24 hours time point, Plasminogen Potency $(3.81 \mathrm{U} / \mathrm{mL})$ and Protein Concentration $(0.64 \mathrm{mg} / \mathrm{mL})$ were out of $\mathrm{AC}$ and Plasmin Activity $(0.027 \mathrm{UI} / \mathrm{mL})$ was found. In subsequent 36 hours time point specific degradation pattern were observed.

Data at $25^{\circ} \mathrm{C}$ indicated that all CQA were compliant with $\mathrm{AC}$ within 72 hours. Despite in subsequent 7 days time point Plasminogen Potency $(5.72 \mathrm{U} / \mathrm{mL})$ and Protein Concentration $(0.84 \mathrm{mg} / \mathrm{mL})$ were compliant, Plasmin Activity $(0.084 \mathrm{UI} / \mathrm{mL}) \mathrm{and}$ Protein Composition (88\%) were not compliant.

CQA remained within acceptance criteria at refrigerated conditions $\left(2-8^{\circ} \mathrm{C}\right)$ for the whole study duration $(1 \mathrm{month})$.

Conclusion: This study provide indications on the product stability for patient use. This data will allow the drug to be stored in more advantageous conditions for the patient.

Biography

Alfonso Salvatore was born on 28 August 1980 in Torre Annunziata (Naples, Italy). Since childhood, he has been passionate about life sciences. He studied Biological Sciences at University of Naples Federico II. He had graduated in 2005. In 2006 he was a fellowship at "The Institute of Biostructure and Bioimaging" of Naples with the task of Expert in molecular diagnostic and pharmaceutical and also gained his $\mathrm{PhD}$ in "Applied Biology" in 2010. This experience was very formative. He had the opportunity to work in a team and to achieve important results in the field of cardiovascular diseases. He was able to gain extensive experience about plasma-derived products.

Publications

1. Haptoglobin Binding to Apolipoprotein A-I Prevents Damage from Hydroxyl Radicals on Its Stimulatory Activity of the Enzyme Lecithin-Cholesterol Acyl-Transferase $\uparrow$ November 2007, Biochemistry 46(39):11158-68, DOI:10.1021/ bi7006349

2. Anti $\llbracket \mathrm{A}$ and anti-B hemagglutinin depletion during Cohn purification process of 5\% immunoglobulin, July 2015 Transfusion 55 Suppl 2(S2):S110-6, DOI: $10.1111 / \operatorname{trf} .13112$

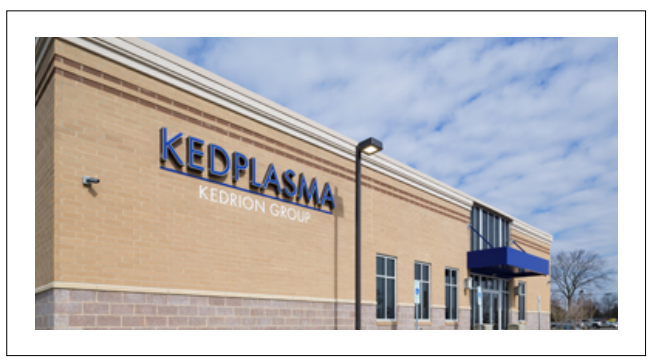

Citation: Alfonso Salvatore, Plasminogen drug product stability study for intended use in ligneous conjunctivitis, Rare Disease 2021,5 th Annual Summit on Rare Diseases and Orphan Drugs, March 18th, 2021,07. 